\title{
Microbial food web dynamics along a soil chronosequence of a glacier forefield
}

\author{
J. Esperschütz ${ }^{1,2}$, A. Pérez-de-Mora ${ }^{1,2}$, K. Schreiner ${ }^{2}$, G. Welzl ${ }^{2}$, F. Buegger ${ }^{3}$, J. Zeyer ${ }^{4}$, F. Hagedorn ${ }^{5}$, J. C. Munch ${ }^{1,3}$, \\ and M. Schloter ${ }^{2}$ \\ ${ }^{1}$ Technical University Munich - Chair of Soil Ecology, Center of Life and Food Sciences Weihenstephan, \\ Ingolstaedter Landstr. 1, 85764 Neuherberg, Germany \\ ${ }^{2}$ Helmholtz Zentrum München, GmbH, German Research Center for Environmental Health, Research Unit of Environmental \\ Genomics, Ingolstaedter Landstr. 1, 85764 Neuherberg, Germany \\ ${ }^{3}$ Helmholtz Zentrum München, GmbH, German Research Center for Environmental Health, Institute of Soil Ecology, \\ Ingolstaedter Landstr. 1, 85764 Neuherberg, Germany \\ ${ }^{4}$ ETH Zürich, Institute of Biogeochemistry and Pollutant Dynamics, Universitätstrasse 16, 8092 Zürich, Switzerland \\ ${ }^{5}$ WSL Birmensdorf, Swiss Federal Institute for Forest, Snow and Landscape Research, Zürcherstrasse 111, \\ 8903 Birmensdorf, Switzerland
}

Received: 11 January 2011 - Published in Biogeosciences Discuss.: 10 February 2011

Revised: 27 September 2011 - Accepted: 25 October 2011 - Published: 11 November 2011

\begin{abstract}
Microbial food webs are critical for efficient nutrient turnover providing the basis for functional and stable ecosystems. However, the successional development of such microbial food webs and their role in "young" ecosystems is unclear. Due to a continuous glacier retreat since the middle of the 19th century, glacier forefields have expanded offering an excellent opportunity to study food web dynamics in soils at different developmental stages. In the present study, litter degradation and the corresponding $\mathrm{C}$ fluxes into microbial communities were investigated along the forefield of the Damma glacier (Switzerland). ${ }^{13} \mathrm{C}$-enriched litter of the pioneering plant Leucanthemopsis alpina (L.) Heywood was incorporated into the soil at sites that have been free from ice for approximately 10, 60, 100 and more than 700 years. The structure and function of microbial communities were identified by ${ }^{13} \mathrm{C}$ analysis of phospholipid fatty acids (PLFA) and phospholipid ether lipids (PLEL). Results showed increasing microbial diversity and biomass, and enhanced proliferation of bacterial groups as ecosystem development progressed. Initially, litter decomposition proceeded faster at the more developed sites, but at the end of the experiment loss of litter mass was similar at all sites, once the more easilydegradable litter fraction was processed. As a result incorporation of ${ }^{13} \mathrm{C}$ into microbial biomass was more evident during the first weeks of litter decomposition. ${ }^{13} \mathrm{C}$ enrichments
\end{abstract}

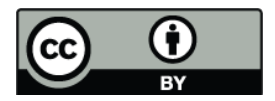

Correspondence to: J. Esperschütz (juergen.esperschuetz@gmx.de) of both PLEL and PLFA biomarkers following litter incorporation were observed at all sites, suggesting similar microbial foodwebs at all stages of soil development. Nonetheless, the contribution of bacteria, especially actinomycetes to litter turnover became more pronounced as soil age increased in detriment of archaea, fungi and protozoa, more prominent in recently deglaciated terrain.

\section{Introduction}

Glaciers are retreating in many mountainous areas of the world due to global warming (Oerlemans, 2005) leaving behind new terrestrial habitats that are colonized by organisms (Bardgett et al., 2007). This is usually a gradual process that results in a chronosequence. The latter can be defined as a set of soils that share a common community of organisms, climate, parent material and slope, but differ in regard with the length of time that materials have been exposed to weathering and soil formation. As glaciers recede, parent materials become exposed and physical and biogeochemical weathering convert primary minerals to secondary minerals releasing plant nutrient elements in soluble forms. Initially, the newly exposed surface typically has a high proportion of rocks, lacks vegetation, is sandy and contains few nutrients (Schütte et al., 2009). As substrate colonization by plants and microorganisms occurs, organic material starts to accumulate that can be further transformed; as a result complex food

Published by Copernicus Publications on behalf of the European Geosciences Union. 
webs develop and stratification into horizons of increasing physical and chemical complexity becomes more prominent (Chapin et al., 1994; Bardgett et al., 2007). These features make chronosequences ideal to study the initial and successional stages of soil and ecosystem development as well as the role of plant-microbe interactions at different time points of soil evolution.

Various studies in alpine regions have recently provided novel insights into microbial community dynamics and their importance in nutrient cycling in these environments. For instance, extensive colonization of granite surfaces could play a crucial role in initial soil formation and mineral dissolution (Frey et al., 2010), but also wind-driven transport of organic material (insects, grasses, seeds) has to be considered (Jumpponen et al., 1999). Although the first phase of soil development is dominated by geological and chemical processes, also biology plays a major role. For example, autotrophic fixation of $\mathrm{C}$ is also known to be an important process during the early stages of soil formation providing, in turn, nutrient sources for heterotrophic microorganisms (Walker and del Moral, 2003). Diazotrophic communities have been shown to be highly diverse following glacier retreat and could have a major role in $\mathrm{N}$ cycling in these ecosystems (Duc et al., 2009). Heterotrophic communities may also be highly abundant at initial soil stages (Tscherko et al., 2003), for instance, in response to ancient $\mathrm{C}$ released during glacier retreat. Microbial communities in glacier forefields have also been shown to respond to changes in ecosystem development (e.g. C and $\mathrm{N}$ content) and vegetation (Tscherko et al., 2005; Miniaci et al., 2007).

Pioneer plants can strongly alter parent materials and stimulate microbe-plant interactions through root morphology, rhizodeposition and litter production (Bardgett et al., 1999; Bardgett and Walker, 2004). The plant residues are transformed by microorganisms into humus and other new organic substances enhancing the capacity of the soil to hold water and nutrients. This positive feedback accelerates the development of more complex plant communities and microbial food web structures (Edwards et al., 2006). Rhizodeposits of pioneering plants such as Leucanthemopsis alpina (L.) Heywood (L. alpina) have been shown to cause significant shifts in the microbial community structure of rhizosphere soil compared to bulk soil at glacier forefields (Edwards et al., 2006). Due to their simple molecular structure root exudates are readily assimilable by single microbes (Baudoin et al., 2003). By contrast, the transformation of litter requires different specialized microorganisms acting as functional units to degrade substances like lignin or cellulose (Dilly et al., 2004; Fioretto et al., 2005). Although microbial interactions during litter degradation might be critical for ecosystem development in such scenarios (Bardgett and Walker, 2004), little is known about microbial dynamics of this process and the main players involved.

To improve our understanding of litter degradation and the role of microbial communities during the initial stages of soil and ecosystem formation, a field incubation experiment using ${ }^{13} \mathrm{C}$ labelled plant litter of L. alpina was carried out in a chronosequence in the Damma Glacier forefield (Switzerland). L. alpina was selected because it was previously described as a pioneering plant in this area (Edwards et al., 2006; Miniaci et al., 2007). Microbes involved in litter degradation were identified via ${ }^{13} \mathrm{C}$ labelling of phospholipid fatty acids (PLFA) and phospholipid ether lipids (PLEL) (Gattinger et al., 2003; White et al., 1979; Zelles, 1999). We hypothesized a different and more complex microbial community structure as soil development progresses. In addition, we expected litter degradation rates to increase accordingly along the chronosequence as a result of better developed microbial foodwebs. To test this, the microbial community profile, litter degradation and incorporation of ${ }^{13} \mathrm{C}$-labelled litter products by microbial communities were studied at four different locations of a chronosequence along a glacier forefield $(10,60,100$ and 700 years free of ice) in bulk and litter amended soil.

\section{Material and methods}

\subsection{Production of labelled plant litter}

L. alpina was sowed in plastic pans filled with prick out substrate in the greenhouse. Seeds were watered daily and incubated for $8-10$ days at $+20 /+15^{\circ} \mathrm{C}$ (day/night) and $75-85 \%$ relative humidity until germination. Subsequently, plants were transferred into plastic pots (4 plants per pot) of $12 \mathrm{~cm}$ in diameter, filled with a mixture of potting soil, expanded clay and silica sand $(1: 1: 2, \mathrm{v} / \mathrm{v} / \mathrm{v})$. The pots were placed in a transparent EFTE-plastic tent (ethylene-tetrafluorethylene, film thickness $80 \mu \mathrm{m}$, Koch Membranen GmbH, 83253 Germany; volume $\sim 7000 \mathrm{~L}$ ) and subjected to a photoperiodic day length of $14 \mathrm{~h}$ (additional light by sodium vapour discharge lamps, SONT Agro 400, Philips, NL). Temperature was kept around $+25 /+18^{\circ} \mathrm{C}$ (day/night) and relative humidity between $75-85 \%$. Irrigation was performed daily via irrigation tubes $(500 \mathrm{~mL} / 24 \mathrm{~h} / 12$ pots $)$. Twice a week $500 \mathrm{~mL}$ of Hoagland based fertilizer was added after irrigation (Hoagland, 1920). The ${ }^{13} \mathrm{C}$ labelling was performed according to Esperschütz et al. (2009). In brief, $\mathrm{CO}_{2}$ concentration in the tent atmosphere was reduced by plant photosynthesis during the daytime. When the $\mathrm{CO}_{2}$ concentration in the tent dropped below $350 \mu \mathrm{mol} \mathrm{mol}^{1}$, enriched ${ }^{13} \mathrm{CO}_{2}\left({ }^{13} \mathrm{C}=+170 \%\right.$ vs. Vienna-Pee Dee Belemnite, Air Liquide, Düsseldorf, Germany) was added to the tent atmosphere, until $\mathrm{CO}_{2}$ concentration reached $400 \mu \mathrm{mol} \mathrm{mol}^{1}$. Using this experimental setup, an enriched ${ }^{13} \mathrm{C}$ atmosphere of +90 to $+110 \%$ V-PDB was established inside the tent. At night time the tent atmosphere was pumped through vials containing soda lime (sodium and calcium hydroxide) using a membrane pump (N 0135.3 AN.18, KNF Neuberger, Freiburg, Germany) with a flow of $200 \mathrm{~L} \mathrm{~min}^{-1}$ 
to reduce the $\mathrm{CO}_{2}$ produced by the plant dark respiration. The $\mathrm{CO}_{2}$ depleted air was pumped into the closed tent again. The system capacity ensured a stable $\mathrm{CO}_{2}$ concentration of $350 \mu \mathrm{mol} \mathrm{mol}^{-1}$ over night. The $\mathrm{CO}_{2}$ concentration of the inner and outer tent atmosphere (day/night) was measured continuously with a photo acoustic $\mathrm{CO}_{2}$ controller (7MB1300, Siemens, Germany, calibration at 400 to $600 \mu \mathrm{mol} \mathrm{mol}^{-1} \pm 2 \%$ ). The labelled plants were harvested before flowering after a total growth time of 10 weeks. Leaves and stems were oven-dried $\left(60^{\circ} \mathrm{C}\right)$, homogenized and shredded $(0.5-2.0 \mathrm{~cm})$. The obtained labelled plant litter of L. alpina $\left(\delta^{13} \mathrm{C}=88.4 \pm 1.6 \%\right.$ ovs. V-PDB $)$ was used in the following experiment.

\subsection{Experimental setup}

The experiment was carried out in the forefield of the Damma glacier, around $2100 \mathrm{~m}$ a.s.l. It is located in the canton Uri in Switzerland (N46 $38.177^{\prime}$ E008 $\left.27.677^{\prime}\right)$ facing north/east. The climate of the area is characterized by a short vegetation period (mid of June to end of September) and approximately $2400 \mathrm{~mm}$ of rainfall per year. It has a total length of $2.35 \mathrm{~km}$ and a total area of $5.09 \mathrm{~km}^{2}$ (measured in 1973). Since the beginning of measurements in 1921, the Damma glacier has retreated at an average rate of $11 \mathrm{~m}$ per year. A detailed description of the research site has been done recently by the BigLink project (Bernasconi et al., 2008; Göransson et al., 2011). Based on this site characteristics as well as systematic measurements by the Swiss Glacier monitoring network (http:// glaciology.ethz.ch/messnetz/glaciers/damma.html), three locations in the forefield of known exposure time since glacier retreat were chosen: (a) the first location near the glacier tongue $\left(\mathrm{N}^{\circ} 6^{\circ} 38.177^{\prime} \mathrm{E} 008^{\circ} 27.677^{\prime}\right)$ with an exposure time of approximately 10 years (T1), (b) a second location (T2) below the 1992 moraine free of ice for nearly 60 years $\left(\mathrm{N} 46^{\circ} 38.177^{\prime} \mathrm{E}^{\circ} 08^{\circ} 27.677^{\prime}\right)$, and (c) a third location near the 1928 moraine ( $\mathrm{N}^{\circ} 6^{\circ} 38.177^{\prime} \mathrm{E} 008^{\circ} 27.677^{\prime}$ ) estimated to be ice-free for around 100 years (T3). Outside the forefield, a fourth location (T4) $\left(\mathrm{N}^{\circ} 6^{\circ} 38.177^{\prime} \mathrm{E} 008^{\circ} 27.677^{\prime}\right)$ free from ice for at least 700 years, served as reference site (Egli et al., 2001).

According to Hämmerli et al. (2007), the bedrock material is Aargranite and surface conditions vary between fine fluvial sands and coarse sandy areas. The soil at the different locations at the forefield can be classified as either Leptosol or Regosol with an average of 50 to $80 \%$ of sand, 10 to $50 \%$ of silt and around $5 \%$ of clay (Dümig et al., 2011). According to Dümig et al. (2011), the organic surface layer increased with increasing soil age, preceding the development of an $A_{h}$ horizon. At T1 hardly any $A_{h}$ horizon could be detected, whereas up to $4 \mathrm{~cm} A_{h}$ was found at T4. Soil pH ranged from 4.3 to 5.6; the lowest value was detected at the reference site $\mathrm{T} 4$. Increasing concentrations of total $\mathrm{C}$ from $0.11 \%$ to $6.50 \%$ and total $\mathrm{N}$ from $0.004 \%$ to $0.442 \%$ were observed as ecosystem development progressed. The soil $\delta^{13} \mathrm{C}$ value was on average $-27 \%$ vs. V-PDB at all locations (Table 1). The young site T1 was characterized by detached vegetation patches of Agrostis gigantea, Rumex scutatus and Cerastium uniflorum resulting in less than $20 \%$ vegetation cover (Göransson et al., 2011), By contrast, T2 was dominated by A. gigantea, Salix sp. and Deschampsia cespitosa (Göransson et al., 2011) showing partial to full vegetation cover (Sigler and Zeyer, 2002). T3 was fully covered by vegetation (Töwe et al., 2010) with Rhododendron ferrugineum, A. gigantea and Festucarubra as dominant plant species. The reference site $\mathrm{T} 4$ was further dominated by Alnus viridis (Göransson et al., 2011). L. alpina was commonly detected at all locations (Edwards et al., 2006; Miniaci et al., 2007; Töwe et al., 2010) and therefore used to produce labelled plant litter in the present experiment.

Following snow melt in the beginning of June 2008, tubes made of aluminium $(20 \mathrm{~cm}$ in diameter and $14 \mathrm{~cm}$ high) were installed $10 \mathrm{~cm}$ deep into the soil and replicated 5 times at every location (T1-T4). Every replicate was composed of three independent tubes: two for soil analysis and one for litterbag study. To avoid damaging of the vegetation cover, it was carefully removed prior to litter application. In the tubes for soil analysis, plant litter (5 $\mathrm{g}$ oven-dried) was applied directly below the vegetation cover $(2-4 \mathrm{~cm}$ depth) to minimize the influence of natural litter breakdown. Then, the vegetation cover was re-accommodated to ensure undisturbed conditions during the experimental period. For the litter bag experiment, two litter bags (mesh-size $40 \mu \mathrm{m}$ ) with $2.5 \mathrm{~g}$ of oven-dried plant material per bag were placed at a similar depth as with the direct litter application. Every tube was protected with steel grids (mesh size $5 \mathrm{~mm}$ ) against disturbances.

Eight and 12 weeks after litter application one litter bag and one of the tubes containing directly applied litter was harvested per location and replicate. Sampled litter bags were immediately placed on ice for transportation and kept frozen until further analysis. The tubes were completely removed from the soil, sealed and transported to the lab for further analysis. Control soil was sampled next to the tubes at similar soil depths at the beginning and at the end of the experiment. The soil was immediately sieved at the forefield and stored on ice for transportation.

\subsection{Soil and litter bag analysis}

Litter degradation rates were calculated based on the loss of litter material in the litter bags during incubation after drying at $60^{\circ} \mathrm{C}$. Soil samples from the tubes were taken from $2-5 \mathrm{~cm}$ depth and remaining litter material was carefully removed. An aliquot of the soil samples was dried at $60^{\circ} \mathrm{C}$ whereas the rest was stored at $-20^{\circ} \mathrm{C}$ for phospholipid analysis. The dried soil and plant litter material were ballmilled and subsequently analysed for total $\mathrm{C},{ }^{13} \mathrm{C}$ and $\mathrm{N}$ content using an elemental analyzer (Eurovector, Milan, Italy) 
Table 1. Total $\mathrm{C}$ and $\mathrm{N}$ contents, $\mathrm{pH}$-values and $\delta^{13} \mathrm{C}$ natural abundance in soil samples of the control treatments without litter application (means of $n=5 \pm$ standard deviation) at different locations (T1-T4).

\begin{tabular}{lllll}
\hline $\begin{array}{l}\text { ecosystem } \\
\text { development }\end{array}$ & $\begin{array}{l}\mathrm{pH} \\
\left(\mathrm{CaCl}_{2}\right)\end{array}$ & $\begin{array}{l}\mathrm{C}_{\text {total }} \\
{[\mathrm{g} / 100 \mathrm{~g}]}\end{array}$ & $\begin{array}{l}\mathrm{N}_{\text {total }} \\
{[\mathrm{g} / 100 \mathrm{~g}]}\end{array}$ & $\begin{array}{l}\delta^{13} \mathrm{C} \\
{[\% \circ \mathrm{V}-\mathrm{PDB}]}\end{array}$ \\
\hline $\mathrm{T} 1-10$ years & $5.6(0.1)$ & $0.11(0.09)$ & $0.004(0.002)$ & $-26.96(2.39)$ \\
$\mathrm{T} 2-60$ years & $4.8(0.1)$ & $0.78(0.55)$ & $0.048(0.034)$ & $-26.50(0.47)$ \\
$\mathrm{T} 3-100$ years & $5.1(0.6)$ & $0.62(0.35)$ & $0.040(0.028)$ & $-27.51(0.56)$ \\
$\mathrm{T} 4>$ 700 years & $4.3(0.2)$ & $6.50(3.96)$ & $0.442(0.252)$ & $-26.72(0.28)$ \\
\hline
\end{tabular}

coupled with an isotope ratio mass spectrometer (MAT 253, Thermo Electron, Bremen, Germany). Soil $\mathrm{pH}$ was analysed in $0.01 \mathrm{M} \mathrm{CaCl}_{2}$ extracts (DIN ISO 10390).

\subsection{Phospholipid analyses}

Phospholipid fatty acid (PLFA) and phospholipid ether lipid (PLEL) analyses were performed based on Zelles et al. (1995) and Gattinger et al. (2003). An aliquot of $50 \mathrm{~g}$ soil (dry weight) was extracted with $250 \mathrm{~mL}$ of methanol, $125 \mathrm{~mL}$ of chloroform and $50 \mathrm{~mL}$ of phosphate buffer $(0.05 \mathrm{M}, \mathrm{pH} 7)$. After $2 \mathrm{~h}$ of horizontal shaking, $125 \mathrm{~mL}$ of water and $125 \mathrm{~mL}$ of chloroform were added to promote phase separation. After $24 \mathrm{~h}$ the water phase was removed and discarded. The total lipid extract was separated into neutral lipids, glycolipids and phospholipids on a silica-bonded phase column (SPE-SI $2 \mathrm{~g} / 12 \mathrm{~mL}$; Bond Elut, Analytical Chem International, CA, USA). An aliquot corresponding to $25 \mathrm{~g}$ of the phospholipid extract (dry weight) was further separated into saturated (SATFA), monounsaturated (MUFA) and polyunsaturated (PUFA) fatty acids (see Zelles et al., 1995 for details) to facilitate the identification of fatty acids as well as to obtain a good baseline separation of peaks for isotopic calculations. According to Wuchter et al. (2003), ${ }^{13} \mathrm{C}$ enriched PLEL isoprenoids indicate archaeal activity. Therefore the remaining extract of the phospholipids equivalent to $25 \mathrm{~g}$ was therefore used for PLEL extraction as described by Gattinger et al. (2003). In brief, after an acidic hydrolysis, ether core lipids were treated with hydriodic acid $(57 \%)$ for $18 \mathrm{~h}$ at $100^{\circ} \mathrm{C}$ to cleave the ether bonds. The resulting alkyl iodides were reduced to the corresponding hydrocarbons using $100 \mathrm{mg}$ zinc powder in glacial acetic acid at $100^{\circ} \mathrm{C}$ for $18 \mathrm{~h}$. The "isoprenoid-20" PLEL (phytane, i20) was used for (ubiquitous) archaeal abundance (Gattinger et al., 2003).

Prior to measurements, an internal standard (nonadecanoic acid methyl ester respectively myristic acid methyl ester) was added to calculate absolute amounts of fatty acids. PLFA were analyzed as fatty acid methyl esters (FAME) on a gas chromatograph/mass spectrometry system (5973MSD GC/MS Agilent Technologies, Palo Alto, USA). FAMEs were separated on a polar column (BPX70, SGE GmbH, Griesheim, Germany), $60 \mathrm{~m} \times 0.25 \mathrm{~mm} \times 0.25 \mu \mathrm{m}$, coated with $70 \%$ of cyanopropyl polysilphenylene-siloxane (see Esperschütz et al., 2009 for details). PLEL were measured using an non-polar column (HP 5 capillary column, $50 \mathrm{~m}$ length, $0.2 \mathrm{~mm}$ internal diameter; coated with a crosslinked $5 \%$ phenylmethyl rubber phase with a film thickness of $0.3 \mu \mathrm{m}$; see Gattinger et al., 2003 for details). The mass spectra of the individual FAME were identified by comparison with established fatty acid libraries (Solvit, $\mathrm{CH}$ 6500 - Luzern, Switzerland) using MSD Chemstation (Version D.02.00.237). The ${ }^{13} \mathrm{C}$ signature of the corresponding PLFA was determined by online coupling of the GC/MS system with an isotope ratio mass spectrometer (Delta Advantage, Thermo Electron Cooperation, Bremen, Germany), after combustion (GC Combustion III, Thermo Electron Cooperation, Bremen, Germany). The actual $\delta^{13} \mathrm{C}$ ratio of the individual FAME was corrected for the one $\mathrm{C}$ atom that was added during derivatisation (Abrajano et al., 1994). Fatty acids are presented by the number of $\mathrm{C}$ atoms followed by the number of double bonds. The positions of double bonds are indicated by " $\omega$ " and the number of the first double-bonded $\mathrm{C}$ atoms from the $\omega$ end of the $\mathrm{C}$ chain. Anteiso and Isobranched fatty acids are indicated by "ant" and "iso", followed by the number of $\mathrm{C}$ atoms. Branched fatty acids in which the position of the double bond was unknown were indicated by the prefix "br". Methyl groups on the tenth C atom from the carboxyl end of the molecule were indicated by "10ME". Cyclopropane fatty acids were indicated by the prefix "cy", while even-chained, saturated fatty acids were abbreviated with the prefix "nor". Since PLFA 18:3 was not detected in any soil sample, removal of litter residues prior to extraction was successful and hence all PLFA were taken into account for statistical analysis and interpretation of data.

\subsection{Calculations}

Stable isotope results were expressed in $\delta^{13} \mathrm{C}$ or atom percent (AP) according to Eqs. (1) and (2):

$$
\begin{aligned}
& \left.\delta^{13} \mathrm{C}=\left[\left(R_{\text {sample }} / R_{\mathrm{V}-\mathrm{PDB}}\right)-1\right] \times 1000\right) \\
& { }^{13} \mathrm{C}_{\mathrm{AP}}=\left(100 \times R_{\mathrm{V}-\mathrm{PDB}} \times\left(\delta^{13} \mathrm{C} / 1000+1\right)\right) / \\
& \left(1+R_{\mathrm{V}-\mathrm{PDB}} \times\left(\delta^{13} \mathrm{C} / 1000+1\right)\right)
\end{aligned}
$$


$\mathrm{R}_{\text {Sample }}$ and $\mathrm{R}_{\mathrm{V}-\mathrm{PDB}}$ represent the ${ }^{13} \mathrm{C}$ to ${ }^{12} \mathrm{C}$ ratios of sample and international standard Vienna-Pee Dee Belemnite (VPDB $=0.0111802)$, respectively. The relative amount of litter-incorporated ${ }^{13} \mathrm{C}$ ( $\%{ }^{13} \mathrm{C}_{\text {LITTER }}$ ) into the total lipid fraction was calculated according to Eq. (3),

$$
\left.\%{ }^{13} \mathrm{C}_{\text {LiTTER }}=\mathrm{C}_{\mathrm{Tx}} \times\left({ }^{13} \mathrm{C}_{\mathrm{Tx}}-{ }^{13} \mathrm{C}_{\mathrm{T} 0}\right) \times 100 /{ }^{13} \mathrm{C}_{\mathrm{added}}\right)
$$

where the concentration of the individual $\mathrm{C}$-fraction (ng g ${ }^{-1} \mathrm{DW}$ ) at timepoint Tx was multiplied by its ${ }^{13} \mathrm{C}$ enrichment in atom percent excess (difference between ${ }^{13} \mathrm{C}$ at timepoint $\mathrm{Tx}$ and ${ }^{13} \mathrm{C}$ enrichment at control) and expressed relatively to the amount of added ${ }^{13} \mathrm{C}\left(\mathrm{ng} \mathrm{g}^{1} \mathrm{DW}\right)$. The relative ${ }^{13} \mathrm{C}$-distribution within total measured phospholipids ( ${ }^{13} \mathrm{C}_{\mathrm{PLDIST}}$ ) was calculated as follows:

$\%^{13} \mathrm{C}_{\text {PLDIST }}=\%{ }^{13} \mathrm{C}_{\text {LITTER }} i \times 100 / \sum \%{ }^{13} \mathrm{C}_{\text {LITTER }}$

where $\%{ }^{13} \mathrm{C}_{\text {LITTER }} i$ represents the relative amount of added ${ }^{13} \mathrm{C}$ in an individual phospholipid $i$, as calculated after Eq. (3). Diversity $\left(H_{k}\right)$ and Evenness $\left(E_{k}\right)$ of the PLFA pattern were calculated using Shannon indices according to Eqs. (5) and (6):

$H_{k}=-\sum_{i=1}^{k} p_{i} \ln p_{i}$

$E_{k}=\frac{H_{k}}{\ln k}$

where $k$ represents the total number of fatty acids and $p_{i}$ the relative abundance of each PLFA (Hill, 1973).

\subsection{Statistical analysis}

Univariate analysis of variance was carried out using SPSS 11.0, with location (T1-T4) and harvesting treatment (control, 8 weeks, 12 weeks) as independent variables. Twoway analysis of variance (ANOVA) was performed to establish significant interactions between location and treatment. Significant differences for specific variables were identified using Duncan's post-hoc test at $p<0.05$ following oneway ANOVA. Principal component analysis (PCA) was performed on the variance-covariance matrix utilizing the statistical software $R$ (http://www.r-project.org). PCA was based on mean values $(n=5)$ of PLFA and ${ }^{13}$ C-PLFA data for each location and time point. The data set for PCA was thus composed of 12 (Fig. 2) and 8 (Fig. 5) average samples $(n=5)$ of each location (T1-T4). Data illustration was performed with Adobe Illustrator CS3 and S-PLUS 8.1.

\section{Results}

\subsection{Microbial plant litter degradation}

After 8 weeks significant plant litter degradation $(p<0.05)$ was observed at all sites T1-T4 (Table 2). Nearly $55 \%$

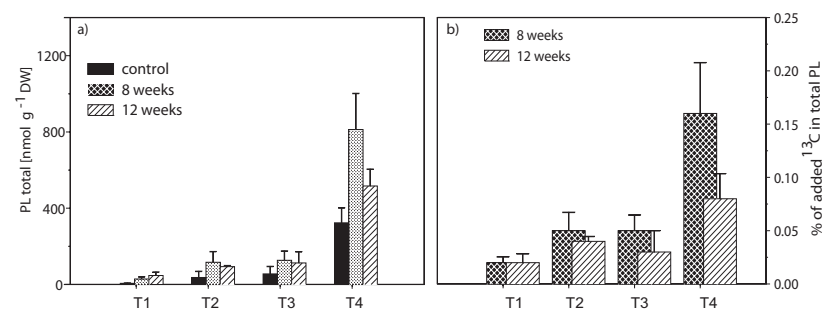

Fig. 1. Total phospholipid (PL) content (a) (nmol g $\left.{ }^{-1} \mathrm{DW}\right)$ and percentage of added ${ }^{13} \mathrm{C}$ incorporated into total PL (b) in soil samples at different stages of ecosystem development T1-T4 in control samples and litter treatments ( 8 and 12 weeks) at individual litter harvesting time points (means + standard deviation, $n=5$ ).

of the applied plant litter was lost at T1, whereas approximately $65 \%$ of the litter material was degraded at the other sites. After 12 weeks no further degradation was observed at T2, T3 and T4. At T1 an extra $10 \%$ mass loss was detected $(p<0.05)$, resulting in a similar amount of degraded residues at all investigated sites at the end of the experiment. Contamination of the total litter mass loss with soil material was excluded, since the total mass loss correlated with the mass loss of C (linear regression, $R^{2}=0.959$, data not shown). Compared to $\mathrm{C}$ the amounts of $\mathrm{N}$ degraded during the incubation period were relatively low (Table 2). As a result, lower $\mathrm{C} / \mathrm{N}$ ratios were found at the end of the experiment $(p<0.05)$. The label in the plant litter ranged between $+81 \%$ and $+89 \% \circ \delta^{13} \mathrm{C}$ (vs V-PDB) and did not significantly change during the incubation period, indicating that the litter material used in the present experimental setup was homogeneously labelled (Table 2).

The total soil PL content increased as ecosystem development progressed with significantly higher values detected at the reference site T4 compared to all other sites $(p<0.05$, Fig. 1a). Due to litter application, the PL content increased irrespective of the site location T1-T4. In general, no differences in PL content were observed between 8 and 12 weeks, except at the reference site T4. In order to compare the amount of ${ }^{13} \mathrm{C}$ incorporated into total PL across different locations in the forefield, the percentage of added ${ }^{13} \mathrm{C}$ that was incorporated into total PL $\left(\%{ }^{13} \mathrm{C}_{\text {LITTER }}\right)$ was calculated relative to the total amount of ${ }^{13} \mathrm{C}$ added. Similar to the total $\mathrm{PL}$ content, an increasing incorporation of ${ }^{13} \mathrm{C}$ derived from plant litter into total PL was detected at T4 compared to the other sites (Fig. 1b), irrespective of the harvesting time point $(p<0.05)$. Between 8 and 12 weeks a slight decrease in ${ }^{13} \mathrm{C}$ in total PL was observed at T2 and T3 (not significant), whilst a $50 \%$ reduction was recorded at $\mathrm{T} 4$ (Fig. $1 \mathrm{~b}, p<0.05$ ).

\subsection{Soil microbial community composition}

Diversity and evenness of the PLFA pattern were calculated according to Eqs. (5) and (6) respectively on the basis of total PL concentrations and the number of fatty acids detected 
Table 2. Litter mass loss and selected plant litter parameters obtained from litter bags during the incubation period along the Damma forefield (means of $n=5 \pm$ standard deviation).

\begin{tabular}{|c|c|c|c|c|c|c|c|c|c|}
\hline & \multirow{2}{*}{$\begin{array}{l}\text { initital plant } \\
\text { litter }\end{array}$} & \multicolumn{4}{|c|}{8 weeks } & \multicolumn{4}{|c|}{12 weeks } \\
\hline & & $\mathrm{T} 1$ & $\mathrm{~T} 2$ & $\mathrm{~T} 3$ & $\mathrm{~T} 4$ & $\mathrm{~T} 1$ & $\mathrm{~T} 2$ & $\mathrm{~T} 3$ & $\mathrm{~T} 4$ \\
\hline plant litter (g per litterbag DW) & 2.50 & $\begin{array}{l}1.12 \\
(0.11)\end{array}$ & $\begin{array}{l}0.95 \\
(0.11)\end{array}$ & $\begin{array}{l}0.91 \\
(0.10)\end{array}$ & $\begin{array}{l}0.87 \\
(0.12)\end{array}$ & $\begin{array}{l}0.88 \\
(0.08)\end{array}$ & $\begin{array}{l}0.84 \\
(0.16)\end{array}$ & $\begin{array}{l}0.83 \\
(0.31)\end{array}$ & $\begin{array}{l}0.93 \\
(0.36)\end{array}$ \\
\hline remaining plant litter ( \%) & 100.00 & $\begin{array}{l}44.68 \\
(4.22)\end{array}$ & $\begin{array}{l}38.03 \\
(4.52)\end{array}$ & $\begin{array}{l}36.27 \\
(3.94)\end{array}$ & $\begin{array}{l}34.90 \\
(4.95)\end{array}$ & $\begin{array}{l}35.14 \\
(3.10)\end{array}$ & $\begin{array}{l}33.50 \\
(6.24)\end{array}$ & $\begin{array}{l}33.21 \\
(12.41)\end{array}$ & $\begin{array}{l}37.40 \\
(14.30)\end{array}$ \\
\hline $\mathrm{C}_{\text {total }}(\mathrm{g}$ per $\mathrm{g}$ litter $\mathrm{DW})$ & $\begin{array}{l}0.96 \\
(0.06)\end{array}$ & $\begin{array}{l}0.59 \\
(0.15)\end{array}$ & $\begin{array}{l}0.42 \\
(0.04)\end{array}$ & $\begin{array}{l}0.42 \\
(0.05)\end{array}$ & $\begin{array}{l}0.40 \\
(0.04)\end{array}$ & $\begin{array}{l}0.45 \\
(0.13)\end{array}$ & $\begin{array}{l}0.38 \\
(0.06)\end{array}$ & $\begin{array}{l}0.37 \\
(0.14)\end{array}$ & $\begin{array}{l}0.42 \\
(0.17)\end{array}$ \\
\hline${ }^{13} \mathrm{C}_{\text {total }}\left(\% \circ \delta^{13} \mathrm{C}\right.$ V-PDB $)$ & $\begin{array}{l}88.35 \\
(1.61)\end{array}$ & $\begin{array}{l}84.00 \\
(4.42)\end{array}$ & $\begin{array}{l}82.33 \\
(4.41)\end{array}$ & $\begin{array}{l}83.47 \\
(4.41)\end{array}$ & $\begin{array}{l}85.53 \\
(3.09)\end{array}$ & $\begin{array}{l}86.50 \\
(2.14)\end{array}$ & $\begin{array}{l}80.19 \\
(7.36)\end{array}$ & $\begin{array}{l}81.04 \\
(3.15)\end{array}$ & $\begin{array}{l}81.45 \\
(5.31)\end{array}$ \\
\hline $\mathrm{N}_{\text {total }}$ (g per g litter DW) & $\begin{array}{l}0.043 \\
(0.004)\end{array}$ & $\begin{array}{l}0.045 \\
(0.011)\end{array}$ & $\begin{array}{l}0.032 \\
(0.004)\end{array}$ & $\begin{array}{l}0.031 \\
(0.007)\end{array}$ & $\begin{array}{l}0.030 \\
(0.003)\end{array}$ & $\begin{array}{l}0.035 \\
(0.012)\end{array}$ & $\begin{array}{l}0.030 \\
(0.006)\end{array}$ & $\begin{array}{l}0.027 \\
(0.011)\end{array}$ & $\begin{array}{l}0.031 \\
(0.012)\end{array}$ \\
\hline $\mathrm{C} / \mathrm{N}$ & $\begin{array}{l}22.70 \\
(1.22)\end{array}$ & $\begin{array}{l}13.32 \\
(0.75)\end{array}$ & $\begin{array}{l}13.31 \\
(0.57)\end{array}$ & $\begin{array}{l}13.57 \\
(1.11)\end{array}$ & $\begin{array}{l}13.35 \\
(0.57)\end{array}$ & $\begin{array}{l}12.98 \\
(0.90)\end{array}$ & $\begin{array}{l}12.85 \\
(0.88)\end{array}$ & $\begin{array}{l}13.86 \\
(0.47)\end{array}$ & $\begin{array}{l}13.40 \\
(1.15)\end{array}$ \\
\hline
\end{tabular}

in the samples (Table 3). Diversity was lowest at T1, irrespective of treatments $(p<0.05)$. After 8 weeks and after 12 weeks of incubation, significantly higher values were obtained for T4 compared to T1 and T2 $(p<0.05)$. A similar trend was observed for the evenness of PLFA.

Figure 2 shows the ordination of the samples using PCA analysis of the various phospholipid fatty acids. Principal components accounted for $47.5 \%$ (PC1) and $20.5 \%$ (PC2) of the total variance, respectively. The first principal component (PC1) shows discrimination between samples from $\mathrm{T} 1$ and T2/T3/T4 sites. The PL biomarkers that correlated best with this axis were PLEL i20 and poly unsaturated fatty acids (18:2w6,9 and 20:4) as well as various iso- and anteiso branched PL (ant14:0, ant15:0, iso15:0, iso16:0, iso17:0) and cyclopropylic PLFA (cy17:0, cy19:0). The biomarkers PLEL i20, 18:2w6,9 and 20:4 were more abundant in the samples derived from T1 and T2, whilst the opposite was observed for the other groups. The second principal component (PC2) separated samples based on the presence or absence of added litter. The variables that contributed the most to the variance explained by this axis were saturated fatty acids of the branched (ant17:0, br18:0, br20:0) and chained type (nor16:0); these were less abundant in litter treatments. On the other hand, mono unsaturated PLFA (16:1w7, 16:1w11, $17: 1 \mathrm{w} 8,18: 1 \mathrm{w} 7$ and 18:1w9) were more abundant in the litter treatments. While PCA was able to differentiate between control and litter-amended samples, there was no clear separation of samples from T1, T2 and T3 within the litteramended treatments.

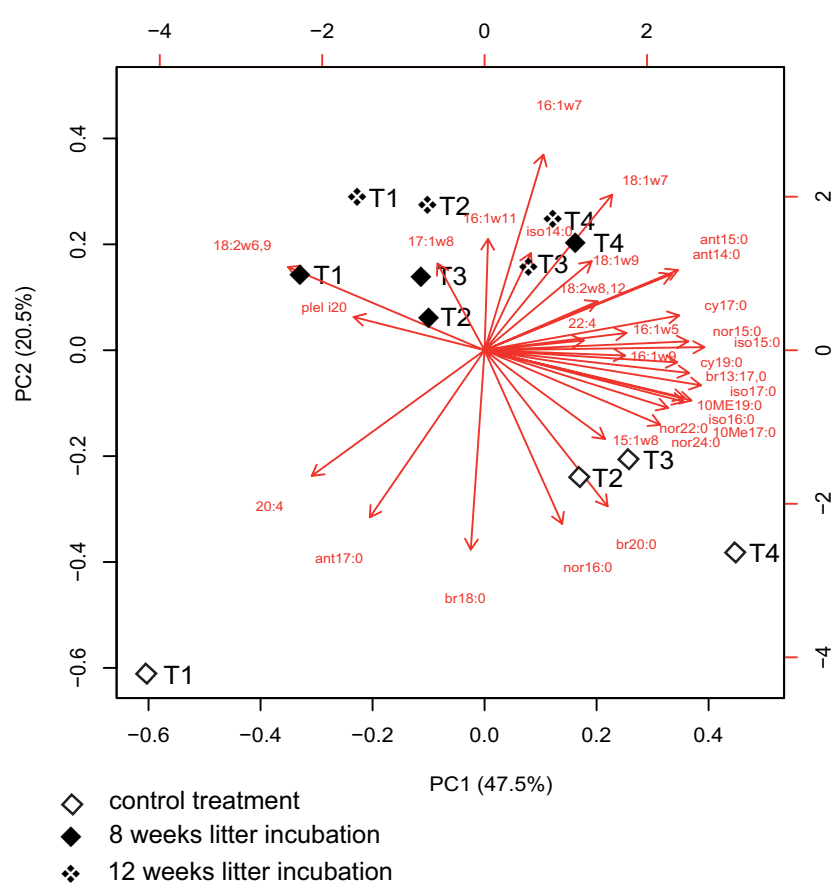

Fig. 2. First $P C 1$ and second $P C 2$ principal components of the principal component analysis (PCA) illustrating the relative ordination of the various locations after 8 and 12 weeks based on their relative abundance in the soil samples (in \% relative to total PL according to Fig. 1; means of $n=5$ ). 
Table 3. Diversity and Evenness of the PLFA pattern (based on Shannon indices) in soil samples at T1-T4 after 8 weeks and 12 weeks of litter application, as well as without litter (control). Values are illustrated as means ( $n=5 \pm$ standard deviation). Letters (a, b, c) indicate significant differences $p<0.05$ within treatments (control, 8 weeks, 12 weeks).

\begin{tabular}{l|cccc|cccc|cccc}
\hline & \multicolumn{4}{|c}{ control } & \multicolumn{4}{c|}{8 weeks } & \multicolumn{3}{c}{12 weeks } \\
& $\mathrm{T} 1$ & $\mathrm{~T} 2$ & $\mathrm{~T} 3$ & $\mathrm{~T} 4$ & $\mathrm{~T} 1$ & $\mathrm{~T} 2$ & $\mathrm{~T} 3$ & $\mathrm{~T} 4$ & $\mathrm{~T} 1$ & $\mathrm{~T} 2$ & $\mathrm{~T} 3$ & $\mathrm{~T} 4$ \\
\hline PLFA & 1.600 & 2.733 & 2.869 & 2.869 & 2.257 & 2.562 & 2.478 & 2.823 & 2.337 & 2.512 & 2.698 & 2.717 \\
Diversity & $(0.154)^{\mathrm{a}}$ & $(0.111)^{\mathrm{b}}$ & $(0.082)^{\mathrm{b}}$ & $(0.033)^{\mathrm{b}}$ & $(0.108)^{\mathrm{a}}$ & $(0.106)^{\mathrm{b}}$ & $(0.147)^{\mathrm{b}}$ & $(0.050)^{\mathrm{c}}$ & $(0.037)^{\mathrm{a}}$ & $(0.053)^{\mathrm{b}}$ & $(0.139)^{\mathrm{c}}$ & $(0.060)^{\mathrm{c}}$ \\
PLFA & 0.667 & 0.839 & 0.861 & 0.850 & 0.685 & 0.777 & 0.752 & 0.830 & 0.687 & 0.762 & 0.819 & 0.834 \\
Evenness & $(0.064)^{\mathrm{a}}$ & $(0.034)^{\mathrm{b}}$ & $(0.025)^{\mathrm{b}}$ & $(0.011)^{\mathrm{b}}$ & $(0.033)^{\mathrm{a}}$ & $(0.032)^{\mathrm{b}}$ & $(0.045)^{\mathrm{b}}$ & $(0.015)^{\mathrm{c}}$ & $(0.011)^{\mathrm{a}}$ & $(0.016)^{\mathrm{b}}$ & $(0.042)^{\mathrm{c}}$ & $(0.018)^{\mathrm{c}}$ \\
\hline
\end{tabular}

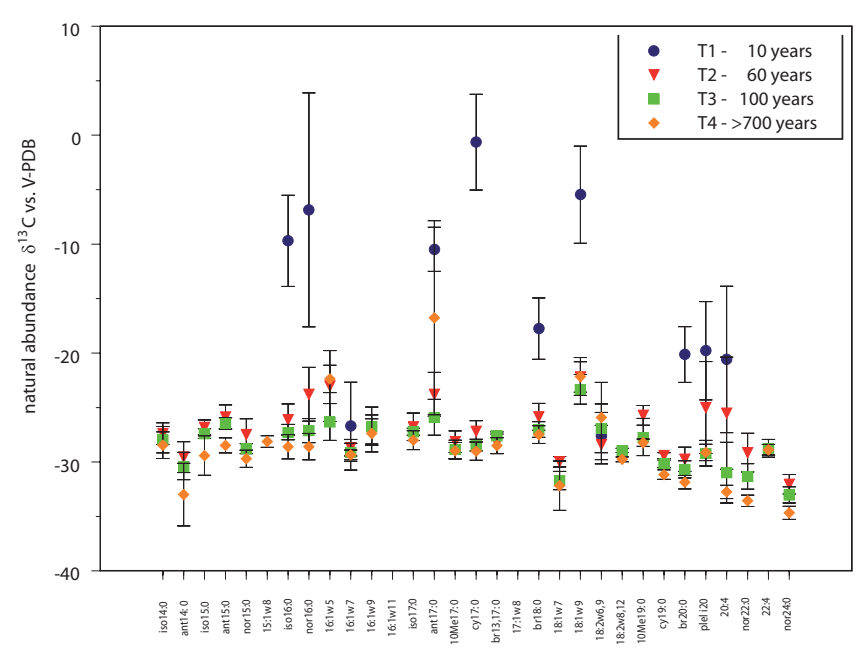

Fig. 3. Natural abundance $\delta^{13} \mathrm{C}$ values [\%o vs V-PDB] of individual PL in control soil without litter application (means \pm standard deviation; $n=5$ ) at different locations T1-T4.

\section{3 $\quad{ }^{13} \mathrm{C}$ distribution within PL groups}

Figure 3 shows the natural ${ }^{13} \mathrm{C}$ abundance (no litter application) of PL in soil at the different sites. For most PL, $\delta^{13} \mathrm{C}$ values ranged between $-25 \%$ and $-30 \%$ at $\mathrm{T} 2, \mathrm{~T} 3$ and $\mathrm{T} 4$, and showed no statistical differences at $p<0.05$ between these sites. T1 showed higher variability of $\delta^{13} \mathrm{C}$ natural abundance with average values ranging between $-1 \%$ and $-20 \%$ (vs V-PDB). In general, $\delta^{13} \mathrm{C}$ natural abundance in PL significantly differed between soil samples from T1 and the other sites, but similar values were observed for 16:1w7 and 18:2w6,9 (Fig. 3).

Distribution of ${ }^{13} \mathrm{C}$ derived from plant litter (PL DIST) among individual PL was calculated according to Eq. (4). Results indicated a similar incorporation of plant litter ${ }^{13} \mathrm{C}$ among individual PL at all sites (Fig. 4). In all cases, the highest plant litter ${ }^{13} \mathrm{C}$ incorporation was reported for 18:2w6,9 (40-50\%), nor16:0, 20:4 and PLEL i20 (10-20\%) and the monounsaturated fatty acids $16: 1 \mathrm{w} 7,18: 1 \mathrm{w} 7$ and 18:1w9 (5-10\%). Litter-derived ${ }^{13} \mathrm{C}$ incorporation patterns

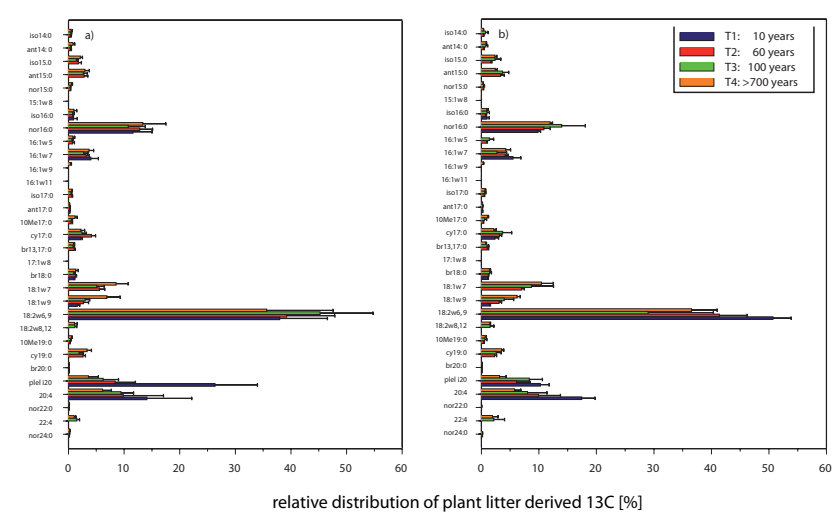

Fig. 4. Distribution of ${ }^{13} \mathrm{C}$ derived from litter (in $\%$ relative to total litter derived ${ }^{13} \mathrm{C}$ into total PL according to Fig. 1; means + standard deviation; $n=5$ ) within phospholipids in soil samples after 8 weeks (a) and 12 weeks (b) of litter incubation at different locations T1T4.

were also assessed by means of PCA analysis (Fig. 5). Principal components accounted for $59.7 \%$ (PC1) and $16.5 \%$ (PC2) of the total variance, respectively. Results showed a separation between $\mathrm{T} 1$ at 8 and 12 weeks and the rest of the sites along PC1. PC1 is very similar to the total soil microbial community profile (Fig. 2); on average, for $\mathrm{T} 1$ there was higher incorporation of ${ }^{13} \mathrm{C}$ into PLFA 18:2w6,9, 20:4 and PLEL i20 at both 8 and 12 weeks compared to the other sites. PC2 mainly separates T4 at 12 weeks from the other sites/treatments, which is mainly related to a higher incorporation of ${ }^{13} \mathrm{C}$ into $16: 1 \mathrm{w} 9$ and $18: 1 \mathrm{w} 9$ as well as the lack of nor22:0 and nor24:0. The separation of T2 and T3 from the other locations at both harvesting time points was due to higher ${ }^{13} \mathrm{C}$ incorporation into cy 17:0 at these sites.

\section{Discussion}

\subsection{Plant litter degradation and microbial biomass}

In the present study, all experimental sites were located in a relatively small geographical region and therefore similar 
climatic and weathering conditions can be assumed. The litter decomposition rate during the first 8 weeks of incubation was high at all sites, and even higher at sites that had been free from ice for at least 60 years (Table 2). This might be explained by the increase in microbial biomass as succession proceeds (Fig. 1; Ohtonen et al., 1999). Nonetheless, after 12 weeks more than $50 \%$ of the applied plant litter was degraded at all locations along the glacier forefield in agreement with previous studies; for instance, Bradford et al. (2002) described a litter mass loss of around $40 \%$ after 5 weeks, although results may vary depending on the type of litter and the mesh size of the bag. It is also possible that the loss of litter mass was not only a result of microbial degradation. Particularly in wet environments, leaching of dissolved organic matter from litter tends to be significant (Chapin et al., 2002). Recently, Gülland and coworkers (unpublished data) found substantial leaching of litter in the Damma glacier forefield. However, the incorporation of litter had a stimulating effect on soil microbial biomass at all investigated sites suggesting that microbial activity was responsible for the observed loss of litter (Dornbush, 2007); after 8 weeks of litter incubation, microbial biomass had doubled at all sites (Fig. 1a). The incorporation of a new $\mathrm{C}$ and energy source into the soil, resulted in the stimulation of zymogenous organisms otherwise present in a dormant state in the soil, regardless of the time free from ice. The freshly-added litter material probably contained considerable amounts of relatively easily degradable substances (Heal et al., 1997). As these compounds are consumed, slow-growing cellulose- and lignin-decomposers start to take over and soon opportunistic organisms, that mainly degrade sugars and amino acids, begin to die of starvation (Tate, 1987; Dilly et al., 2004). This was reflected by a decrease in soil microbial biomass at all sites after 8 weeks, except T1 (Fig. 1a). Results from ${ }^{13} \mathrm{C}$ incorporation into microbial biomass not only support the above-mentioned trend but also underpin that such turnover becomes faster as soil development progresses (Fig. 1b).

Despite the fact that we tried to minimize the effect of the vegetation cover and its rhizosphere by applying the litter below it and sampling the soil underneath the litter bags, indirect effects due to the vegetation cover such as soil moisture, the presence/absence of mycorrhiza or the association of certain faunal decomposer communities could have influenced our results. In addition it cannot be excluded completely that differences in microclimatic conditions at the different sites present may have influenced litter degradation rates (Kaufmann, 2001; Bardgett et al., 2005), which also includes soil moisture influenced by the large amounts of melt water or snow accumulation in certain areas along the forefield (Darmody and Thorn, 1997; Herron et al., 2009).

\subsection{Soil microbial community profile}

According to the diversity of the PLFA pattern, the microbial diversity and evenness were suggested to be significantly lower at T1 compared to the other sites (Table 3). As soil development progresses and the parent material becomes more accessible for plant colonization, complexity increases, nutrient content improves and new potential niches and microniches become available (Loreau, 2001). This, in turn, results in enhanced microbial diversity (Hättenschwiler et al., 2005). The harsh alpine conditions, however, may limit diversity in these environments as suggested by similar indices in T2 and T3. Higher evenness usually reflects higher functionality and stability within a system (Legrende and Legrende, 1998). This becomes more apparent when diversity values between control and litter amended treatments are compared. At $\mathrm{T} 1$, diversity substantially increased in the litter amended treatments, whereas no changes were observed at the older sites (Table 3). The fact that few changes in evenness were observed following litter incorporation may suggest an increasing stability of the microbial food web irrespective of nutrient sources, as succession proceeds.

The initial microbial community structure as evidenced by PLFA analysis of controls (no litter incorporation) indicated marked differences between the T1 and T2-T3 sites, and T4 (Fig. 2). At T1, the microbial community structure was dominated by PLEL i20. 20:4 and 18:2w6,9, whereas their abundance decreased as soil age increased. According to the literature, these markers are mainly found in archaea, fungi, microeukaryotes, protozoa and cyanobacteria (Gattinger et al., 2003; Zelles et al., 1999; Zaady et al., 2010; Potts et al., 1987; Villanueva et al., 2004). These organisms form microbial mats in initial ecosystem substrates (Villanueva et al., 2004; Stal, 1995) to revert on different skills of $\mathrm{C}$ and $\mathrm{N}$ fixation systems (Nisbet and Fowler, 1999), which also allow the use of $\mathrm{C}-\mathrm{CO}_{2}$ or old $\mathrm{C}$ sources. In contrast to data from Töwe et al. (2010), where higher abundance of archaeal ammonia oxidizers was observed as ecosystem development progressed, results from this study indicated a high proportion of total archaea at $\mathrm{T} 1$. This contradictory result might be explained by the fact that Töwe et al. (2010) focused on specific archaeal communities rather than the total archaeal community (based on the ubiquitious archaeal lipid phytane; Gattinger et al., 2003). In comparison with T1, a more bacterial-dominated microbial population was detected at the control sites T2, T3 and T4. Biomarkers characteristic of both Gram-positive bacteria (ant14:0, ant15:0, iso15:0, iso16:0, iso17:0) and Gramnegative bacteria (cy17:0, cy19:0) were more abundant at the older sites. According to Kramer and Gleixner (2008), bacteria prefer plant derived C rather than soil derived $\mathrm{C}$ as a $\mathrm{C}$-source. Vegetation and plant cover were generally greater at these sites likely providing better growth conditions for bacteria.

The microbial community structure detected in control treatments differed from that in the litter treatments at all 
stages of ecosystem development (Fig. 2). After litter application, an increase of mainly Gram-negative bacteria was observed (16:1w7, 16:1w11, 17:1w8, 18:1w7 and 18:1w9) that benefited from the fresh and easily available $C$ sources. This is in accordance with other studies postulating Gramnegatives as an important group of bacteria involved in the litter decomposition process (Elfstrand et al., 2008; Kramer and Gleixner, 2008). Despite a significant decrease in microbial biomass between 8 and 12 weeks of incubation (Fig. 1), differences between both harvesting time points in PLFA profiles of soils amended with litter were not as pronounced as those found between litter-amended and control samples (Fig. 2). This suggests that shifts in the dominant microbial populations from more opportunistic groups to more specialized groups capable to process the more recalcitrant litter components was slow and thus not clearly detectable within the four weeks interval. In addition, differences in the microbial community structure between litteramended treatments from T1, T2 and T3 were not as prominent as those between T4 and the other sites (Fig. 2). The influence of run-off transport of materials from the glacier end to sites T2 and T3 compared to the reference site T4 (not influenced by run-off from the glacier end), and the lack of major variations in soil chemistry between $\mathrm{T} 2$ and $\mathrm{T} 3$ may explain the lack of greater differences between the two and also between $\mathrm{T} 2-\mathrm{T} 3$ and $\mathrm{T} 1$.

\section{3 ${ }^{13} \mathrm{C}$ distribution within PL groups}

There was a high natural ${ }^{13} \mathrm{C}$ abundance of individual PL groups in $\mathrm{T} 1$ with $\delta^{13} \mathrm{C}$ values up to $+0 \%$ (vs V-PDB) (Fig. 3). We do not attribute these high $\delta^{13} \mathrm{C}$ values to the direct use of ancient $\mathrm{C}$ after glacier retreat as suggested by Bardgett et al. (2007), as the $\delta^{13} \mathrm{C}$ values of natural soil organic matter were not higher at $\mathrm{T} 1$ compared to those found at the other sites. The high natural ${ }^{13} \mathrm{C}$ abundance at $\mathrm{T} 1$ might be an indication of cyanobacterial fixation of $\mathrm{C}$ (Walker and del Moral, 2003). Due to a smaller isotopic fractionation by the 3-hydroxypropionate pathway compared to the Calvin cycle, ${ }^{13} \mathrm{C}$ enriched signatures may also occur due to $C$ fixation by cyanobacteria (van der Meer et al., 2007). By predation and release of the fixed $\mathrm{C}$ into the soil matrix and subsequent uptake by other microbes, enriched ${ }^{13} \mathrm{C}$ signatures were possibly transferred into a variety of "noncyanobacterial" PL groups. For instance high $\delta^{13} \mathrm{C}$ values in PLFA biomarkers indicative for Gram-positive and Gramnegative bacteria were also detected. In addition, as ecosystem development progresses, the influence of organic sources from plants increases. Higher plants fix $\mathrm{C}$ through the Calvin cycle resulting in higher influence of $\delta^{13} \mathrm{C}$ signatures within the range -20 to $-25 \% \circ \delta^{13} \mathrm{C}$ (vs V-PDB) in biolipids at $\mathrm{T} 2-\mathrm{T} 3$ and $\mathrm{T} 4$.

Incorporation of ${ }^{13} \mathrm{C}$ into PL was highest for 18:2w6,9 both at 8 and 12 weeks (Fig. $4 \mathrm{a}$ and b), possibly due to a predominant role of fungi during the initial stages of

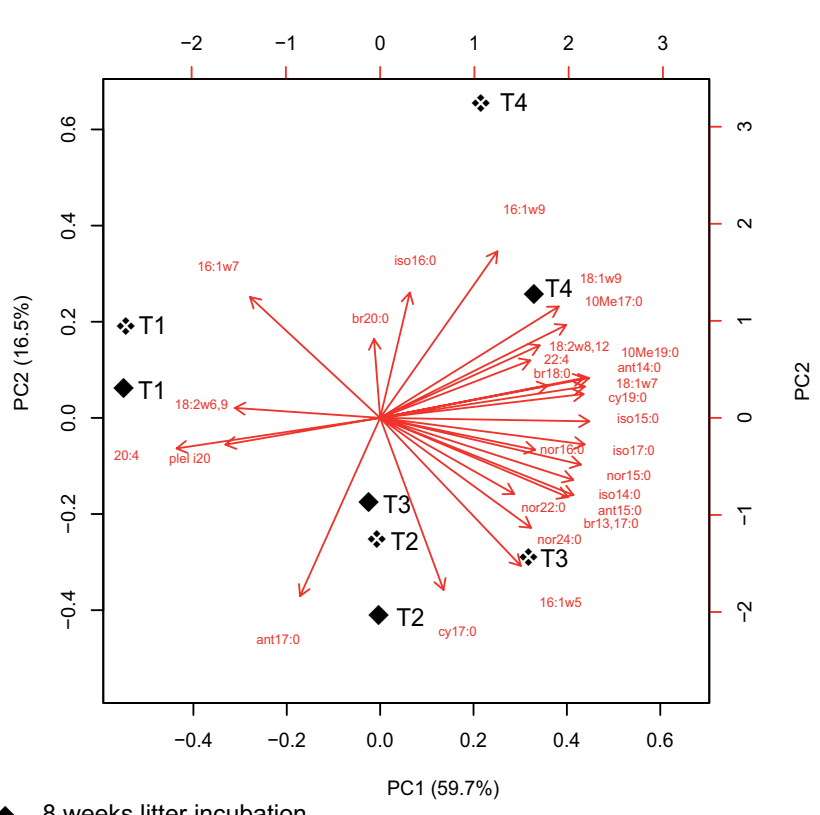

- 8 weeks litter incubation

* 12 weeks litter incubation

Fig. 5. First $P C 1$ and second $P C 2$ principal components of the principal component analysis (PCA) illustrating the relative ordination of the various locations after 8 and 12 weeks based on their ${ }^{13} \mathrm{C}$ litter enriched soil PL profiles (in $\%$ relative to total ${ }^{13} \mathrm{C}$ derived from litter into total PL according to Fig. 1; means of $n=5$ ).

litter decomposition (Fig. 5). According to Emerenciano et al. (1986), high contents of sesquiterpene lactones are known in the family of Asteraceae and up to 7 different compounds have been detected in the Leucanthemopsis genus. As such compounds are difficult to degrade (Picman, 1987), fungi might have played an important role as the main litter decomposers in our study. For instance, fungi secrete enzymes that break down the cuticule of dead leaves (Chapin et al., 2002). Schmidt and Lipson (2004) suggest that a high proportion of fungi may dominate the microbial community structure at low temperatures $\left(-5\right.$ to $\left.3^{\circ} \mathrm{C}\right)$, decomposing litter and immobilizing N. Frey et al. (2003) postulated a translocation of litter-derived $\mathrm{C}$ belowground by decomposer fungi, subsequently stabilized as soil organic matter. The high ${ }^{13} \mathrm{C}$ enrichment detected in 20:4 could be related to protozoa and other soil microfauna which prey on fungi (Georgieva et al., 2005). However, 18:2w6,9 may occur not only in fungi, but also among cyanobacteria (Zaady et al., 2010) and $\gamma$ proteobacteria (Nichols and McMeekin, 2002), which have been detected in the Damma forefield as well (Duc et al., 2009). Therefore, it might be possible that at the young site, the ${ }^{13} \mathrm{C}$ enrichment in these lipids observed in the control soil (no litter application) originates from cyanobacterial ${ }^{13} \mathrm{C}$ fixation, whereas ${ }^{13} \mathrm{C}$ enrichment in 18:2w6,9 after litter application indicates decomposition processes by fungi or $\gamma$-proteobacteria. High amounts of ${ }^{13} \mathrm{C}$ derived from litter 
were also detected in PLFA nor16:0; however, these lipids are ubiquitously found in all organisms and therefore provide no clear bioindication.

Surprisingly, we found significant ${ }^{13} \mathrm{C}$ enrichment in PLEL i20, characteristic of archaea, particularly after 12 weeks (Fig. 4a and b). To the best of our knowledge this is the first litter decomposition study that includes PLEL as archaeal biomarker (at least in alpine ecosystems), suggesting that archaea might play an important role during initial litter decomposition in alpine ecosystems. However, it remains unclear whether the enrichment observed is due to the direct participation of archaea in litter degradation or to the recycling of ${ }^{13} \mathrm{C}$ from other groups. The average incorporation of ${ }^{13} \mathrm{C}$ into archaeal biomass decreased with increasing soil age at 8 and 12 weeks (Figs. 4 and 5), whilst the opposite trend was observed for biomarkers characteristic of Gram-negative bacteria (16:1w7, 18:1w7 or 18:1w9).

Aside from 18:2w6,9 and PLEL i20, subtle differences between sites were observed for the incorporation of ${ }^{13} \mathrm{C}$ into various $\mathrm{PL}$ as reflected by the multivariate analysis (Fig. 5). Incorporation of ${ }^{13} \mathrm{C}$ into 16:1w7 (Gram-negative bacteria) at 12 weeks was greater on average in $\mathrm{T} 1$ compared to the other sites (Fig. $4 \mathrm{a}$ and b). Incorporation of ${ }^{13} \mathrm{C}$ into PLFA cy 17:0 at 8 weeks differed between T2 and the rest of locations (Fig. 4a); this marker is characteristic of certain Gramnegative bacteria. Nonetheless, similar litter-derived ${ }^{13} \mathrm{C}$ incorporation patterns for all PLFA groups were found regardless of site age (Fig. 4a and b). These results indicate that initial food web structures also form the basis of later stages of soil development in this kind of environments. This might be related to the demanding specialization required to survive and proliferate in environments characterized by very low temperatures, short vegetation periods and low availability of nutrients. Microbial populations thus have to react rapidly to organic inputs, which might be restricted to the short vegetation period, and also to compete with plants for the scarce nutrients. It should be noted that results from general PL analyses (Sect. 4.2) showed a stimulation of individual PL groups following litter application which may not necessarily be related to the utilization of litter derived ${ }^{13} \mathrm{C}$. This might be explained by an increase in soil organic carbon mineralization due to the input of fresh organic carbon residues, the so called "priming effect" (Kuzyakov, 2010). Additionally, during the time between litter application and the first harvest ( 8 weeks), microbes may have migrated to other sites through deposition of particulate matter, air currents, precipitation or snowmelt (Schütte et al., 2009). The importance of such disturbances and mechanisms was not estimated in the present study.

\section{Conclusions}

The main points emerging from this study are:

- Soil development increases microbial biomass, diversity and evenness of the PLFA pattern in glacier foreland resulting in faster turnover rates during the first weeks of litter degradation in response to organic source pulses.

- Soil development strongly influences the structure of the microbial community in glacier forefields with increasing importance of bacteria as soil development progresses.

- Adaptation to the harsh environmental conditions prevailing in alpine ecosystems acts as a strong selective force resulting in similar microbial food web patterns at different stages of soil development.

- Cyanobacteria may play a more important role in Ccycling in alpine ecosystems than previously thought.

- In addition to fungi, both Gram-negative bacteria and archaea are significantly involved in C-turnover in response to the incorporation of litter residues in alpine forefields.

\section{Supplementary material related to this article is available online at: http://www.biogeosciences.net/8/3283/2011/ bg-8-3283-2011-supplement.pdf.}

Acknowledgements. This study is part of the Transregional Collaborative Research Centre 38 (SFB/TRR38) which is financially supported by the Deutsche Forschungsgemeinschaft (DFG, Bonn) and the Brandenburg Ministry of Science, Research and Culture (MWFK, Potsdam). We thank C. Kollerbauer for her excellent work in PLFA and PLEL analyses. We are also very grateful to the Department of Environmental Engineering at the Helmholtz Zentrum München for providing labelling tents and facilities in the greenhouse. The following people are acknowledged for their support and their help during the experiment at the glacier forefield: A. Albert, K. Gülland, F. Haesler, B. Hai, J. Ollivier, K. Schauss, R. Schilling, E. Schreiner, S. Schulz, R. Smittenberg, S. Töwe.

Edited by: M. Bahn 


\section{References}

Abrajano, J. T. A., Murphy, D. E., Fang, J., Comet, P., and Brooks, J. M.: ${ }^{13} \mathrm{C} /{ }^{12} \mathrm{C}$ ratios in individual fatty acids of marine mytilids with and without bacterial symbionts, Org. Geochem., 21, 611617, 1994.

Bardgett, R. D. and Walker, L. R.: Impact of coloniser plant species on the development of decomposer microbial communities following deglaciation, Soil Biol. Biochem., 36, 555-559, 2004.

Bardgett, R. D., Mawdsley, J. L., Edwards, S., Hobbs, P. J., Rodwell, J. S., and Davies, W. J.: Plant species and nitrogen effects on soil biological properties of temperate upland grasslands, Funct. Ecol., 13, 650-660, 1999.

Bardgett, R. D., Bowman, W. D., Kaufmann, R., and Schmidt, S. K.: A temporal approach to linking aboveground and belowground ecology, Trends in Ecology \& Evolution, 20, 634-641, 2005.

Bardgett, R. D., Richter, A., Bol, R., Garnett, M. H., Baeumler, R., Xu, X., Lopez-Capel, E., Manning, D. A. C., Hobbs, P. J., Hartley, I. R., and Wanek, W.: Heterotrophic microbial communities use ancient carbon following glacial retreat, Biology Lett., 3, 487-490, 2007.

Baudoin, E., Benizri, E., and Guckert, A.: Impact of artificial root exudates on the bacterial community structure in bulk soil and maize rhizosphere, Soil Biol. Biochem., 35, 1183-1192, 2003.

Bernasconi, S. M. and Biglink Project Members: Weathering, soil formation and initial ecosystem evolution on a glacier forefield: a case study from the Damma Glacier, Switzerland, Mineral. Mag., 72, 19-22, 2008.

Bradford, M. A., Tordoff, G. M., Eggers, T. J., and Newingtont, H. J. E.: Microbiota, fauna, and mesh size interactions in litter decomposition, Oikos, 99, 317-323, 2002.

Chapin, F. S., Walker, L. R., Fastie, C. L., and Sharman, L. C.: Mechanisms of Primary Succession Following Deglaciation at Glacier Bay, Alaska, Ecol. Monogr., 64, 149-175, 1994.

Chapin, F. S., Matson, P. A., and Mooney, H. A.: Principles of Terrestrial Ecosystem Ecology, Springer, New York, 2002.

Darmody, R. G. and Thorn, C. E.: Elevation, age, soil development, and chemical weathering at Storbreen, Jotunheimen, Norway Geogr. Ann., 79A, 215-222, 1997.

Dilly, O., Bloem, J., Vos, A., and Munch, J. C.: Bacterial Diversity in Agricultural Soils during Litter Decomposition, Appl. Environ. Microb., 70, 468-474, 2004.

DIN ISO 10390: Determination of pH., Berlin, Germany, Beuth Verlag GmbH, 1997.

Dornbush, M. E.: Grasses, litter, and their interaction affect microbial biomass and soil enzyme activity, Soil Biol. Biochem., 39, 2241-2249, 2007.

Duc, L., Neuenschwander, S., Rehrauer, H., Wagner, U., Sobek, J., Schlapbach, R., and Zeyer, J.: Development and experimental validation of a nifH oligonucleotide microarray to study diazotrophic communities in a glacier forefield, Environ. Microbiol., 11, 2179-2189, 2009.

Dümig, A., Smittenberg, R. H., and Kögel-Knabner, I.,: Concurrent evolution of organic and mineral components during initial soil development after retreat of the Damma glacier, Switzerland, Geoderma, 163, 83-94, 2011.

Edwards, I., Bürgmann, H., Miniaci, C., and Zeyer, J.: Variation in Microbial Community Composition and Culturability in the Rhizosphere of Leucanthemopsis alpina (L.) Heywood and Adjacent
Bare Soil Along an Alpine Chronosequence, Microb. Ecol., 52, 679-692, 2006.

Egli, M., Fitze, P., and Mirabella, A.: Weathering and evolution of soils formed on granitic, glacial deposits: results from chronosequences of Swiss alpine environment, Catena, 45, 19-47, 2001.

Elfstrand, S., Lagerlöf, J., Hedlund, K., and Mårtensson, A.: Carbon routes from decomposing plant residues and living roots into soil food webs assessed with ${ }^{13} \mathrm{C}$ labelling, Soil Biol. Biochem., 40, 2530-2539, 2008.

Emerenciano de P., V., Auxiliadora, M., Kaplan, C., Gottlieb, O. R., Bonfanti de M., M. R., Ferreira, Z. S., and Comegno, L. M. A.: Evolution of sesquiterpene lactones in asteraceae, Biochem. Syst. Ecol., 14, 585-589, 1986.

Esperschütz, J., Buegger, F., Winkler, J. B., Munch, J. C., Schloter, M., and Gattinger, A.: Microbial response to exudates in the rhizosphere of young beech trees (Fagus sylvatica L.) after dormancy, Soil Biol. Biochem., 41, 1976-1985, 2009.

Fioretto, A., Di Nardo, C., Papa, S., and Fuggi, A.: Lignin and cellulose degradation and nitrogen dynamics during decomposition of three leaf litter species in a Mediterranean ecosystem, Soil Biol. Biochem., 37, 1083-1091, 2005.

Frey, B., Rieder, S. R., Brunner, I., Plötze, M., Koetzsch, S., Lapanje, A., Brandl, H., and Furrer, G.: Weathering-associated bacteria from the Damma Glacier forefield: Physiological capabilities and impact on granite dissolution, Appl. Environ. Microb., 76, 4788-4796, 2010.

Frey, S. D., Six, J., and Elliott, E. T.,: Reciprocal transfer of carbon and nitrogen by decomposer fungi at the soil-litter interface, Soil Biol. Biochem., 35, 1001-1004, 2003.

Gattinger, A., Günthner, A., Schloter, M., and Munch, J. C.: Characterization of Archaea in soils by polar lipid analysis, Acta Biotechnol., 23, 21-28, 2003.

Georgieva, S., Christensen, S., and Stevnbak, K.: Nematode succession and microfauna-microorganism interactions during root residue decomposition, Soil Biol. Biochem., 37, 1763-1774, 2005.

Göransson, H., Olde Venterink, H., and Bååth, E.: Soil bacterial growth and nutrient limitation along a chronosequence from a glacier forefield, Soil Biol. Biochem., 43, 1333-1340, 2011.

Hämmerli, A., Waldhuber, S., Miniaci, C., Zeyer, J., and Bunge, M.: Local expansion and selection of soil bacteria in a glacier forefield, Eur. J. Soil Sci, 58, 1437-1445, 2007

Hättenschwiler, S., Tiunov, A. V., and Scheu, S.: Biodiversity and litter decomposition in terrestrial ecosystems, Annu. Rev. Ecol. Evol. Syst., 36, 191-218, 2005.

Heal, O. W., Anderson, J. M., and Swift, M. J.: Plant litter quality and decomposition: an historical overview, in: driven by nature, Plant litter quality and decomposition, edited by: Cadisch, G. and Giller, K. E., CAB International, Wallingford, United Kingdom, 1997.

Herron, P. M., Stark, J. M., Holt, C., Hooker, T., and Cardon, Z. G.: Microbial growth efficiencies across a soil moisture gradient assessed using ${ }^{13} \mathrm{C}$-acetic acid vapour and ${ }^{15} \mathrm{~N}$-ammonia gas, Soil Biol. Biochem., 41, 1262-1269, 2009.

Hill, M. O.: Diversity and Evenness: A unifying notation and its consequences, Ecology, 54, 427-432, 1973.

Jumpponen, A., Vare, H., Matteson, K. G., Ohtonen, R., and Trappe, J. M.: Characterization of "safe sites" for pioneers in primary succession on recently deglaciated terrain, J. Ecol., 87, 
98-105, 1999.

Kaufmann, R.: Invertebrate succession on an alpine glacierforeland, Ecology, 82, 2261-2278, 2001

Kramer, C. and Gleixner, G.: Soil organic matter in soil depth profiles: Distinct carbon preferences of microbial groups during carbon transformation, Soil Biol. Biochem., 40, 425-433, 2008.

Kuzyakov, Y.: Priming effects: Interactions between living and dead organic matter, Soil Bio. Biochem., 42, 1363-1371, 2010.

Legrende, P.: Legrende L Numerical ecology, Elsevier, Amstersdam, The Netherlands, 1998.

Loreau, M.: Microbial diversity, producer-decomposer interactions and ecosystem processes: a theoretical model, Proc. R. Soc. London Ser. B, 268, 303-309, 2001.

Miniaci, C., Bunge, M., Duc, L., Edwards, I., Bürgmann, H., and Zeyer, J.: Effects of pioneering plants on microbial structures and functions in a glacier forefield, Biol. Fert. Soils, 44, 289297, 2007.

Nichols, D. S. and McMeekin, T. A.: Biomarker techniques to screen for bacteria that produce polyunsaturated fatty acids, J. Microbiol. Meth., 48, 161-170, 2002.

Nisbet, E. G. and Fowler, C. M. R.: Archaen metabolic evolution of microbial mats, P. R. Soc. Lond. B. Bio., 266, 2375-2382, 1999.

Oerlemans, J.: Extracting a climate signal from 169 glacier records, Science, 308, 675-677, 2005.

Ohtonen, R., Fritze, H., Pennanen, T., Jumpponen, A., and Trappe, J.: Ecosystem properties and microbial community changes in primary succession on a glacier forefront, Oecologia, 119, 239246, 1999.

Picman, A. K.: Persistence and disappearance of the sesquiterpene lactone, isoalantolactone, in soils, Biochem. Syst. Ecol., 15, 361363, 1987.

Potts, M., Olie, J. J., Nickels, J. S., Parsons, J., and White, D. C.: Variation in phospholipid ester-linked fatty acids and carotenoids of desiccated nostoc commune (cyanobacteria) from different geographic locations., Appl. Environ. Microb., 53, 4-9, 1987.

Schmidt, S. K. and Lipson, D. A.: Microbial growth under the snow: Implications for nutrient and allelochemical availability in temperate soils Plant Soil, 259, 1-7, 2004.

Schuette, U. M. E., Abdo, Z., Bent, S. J., Williams, C. J., Schneider, G. M., Solheim, B., and Forney, L. J.: Bacterial succession in a glacier foreland of the High Arctic, ISME J., 3, 1258-1268, 2009.

Sigler, W. V. and Zeyer, J.,: Microbial diversity and activity along the forefields of two receding glaciers, Microb. Ecol., 43, 397407, 2002.

Stal, L. J.: Tansley Review No. 84, Physiological ecology of cyanobacteria in microbial mats and other communities, New Phytol., 131, 1-32, 1995.
Tate, R. III. Soil organic matter, biological and ecological effects, John Wiley \& Sons Inc, USA, 291 pp., 1987.

Töwe, S., Albert, A., Kleineidam, K., Brankatschk, R., Dümig, A., Welzl, G., Munch, J., Zeyer, J., and Schloter, M.: Abundance of microbes involved in nitrogen transformation in the rhizosphere of Leucanthemopsis alpina (L.) Heywood grown in soils from different sites of the Damma glacier forefield, Microb. Ecol., 60, 762-770, 2010.

Tscherko, D., Rustemeier, J., Richter, A., Wanek, W., and Kandeler, E.: Functional diversity of the soil microflora in primary succession across two glacier forelands in the Central Alps, Eur. J. Soil Sci., 54, 685-696, 2003.

Tscherko, D., Hammesfahr, U., Zeltner, G., Kandeler, E., and Böcker, R.: Plant succession and rhizosphere microbial communities in a recently deglaciated alpine terrain, Basic Appl. Ecol., 6, 367-383, 2005.

Van Der Meer, M. T. J., Schouten, S., Damsté, J. S. S., and Ward, D. M.: Impact of carbon metabolism on ${ }^{13} \mathrm{C}$ signatures of cyanobacteria and green non-sulfur-like bacteria inhabiting a microbial mat from an alkaline siliceous hot spring in Yellowstone National Park (USA), Environ. Microbiol., 9, 482-491, 2007.

Villanueva, L., Navarrete, A., Urmeneta, J., White, D. C., and Guerrero, R.: Combined phospholipid biomarker-16S rRNA gene denaturing gradient gel electrophoresis analysis of bacterial diversity and physiological status in an intertidal microbial mat, Appl. Environ. Microb., 70, 6920-6926, 2004.

Walker, L. R. and del Moral, R.: Primary succession and ecosystem rehabilitation, Cambridge, UK: Cambridge University Press, 2003.

White, D. C., Davis, W. M., Nickels, J. S., King, J. D., and Bobbie, R. J.: Determination of the sedimentary microbial biomass by extractible lipid phosphate, Oecologia, 40, 51-62, 1979.

Wuchter C., Schouten, S., Boschker, H. T. S. and Damsté, J. S. S.: Biocarbonate uptake by marine Crenarchaeota, FEMS Microbiol. Let. 219, 203-207, 2003.

Zaady, E., Ben-David, E. A., Sher, Y., Tzirkin, R., and Nejidat, A.: Inferring biological soil crust successional stage using combined PLFA, DGGE, physical and biophysiological analyses, Soil Biol. Biochem., 42, 842-849, 2010.

Zelles, L.: Fatty acid patterns of phospholipids and lipopolysaccharides in the characterisation of microbial communities in soil: a review, Biol. Fert. Soils, 29, 111-129, 1999.

Zelles, L., Bai, Q. Y., Rackwitz, R., Chadwick, D., and Beese, F.: Determination of phospholipid- and lipopolysaccharide-derived fatty acids as an estimate of microbial biomass and community structure in soils, Biol. Fert. Soils, 19, 115-123, 1995. 